\title{
Haemodynamic effects of oral salbutamol alone and in combination with sublingual isosorbide dinitrate in patients with severe congestive cardiac failure
}

\author{
J D STEPHENS, S O BANIM, R A J SPURRELL \\ From the Department of Cardiology, St. Bartholomew's Hospital, London
}

SUMMARY To examine possible augmentation of the effects of isosorbide dinitrate by salbutamol, haemodynamic measurements were made in 10 patients with severe chronic congestive cardiac failure who received isosorbide dinitrate 2.5 to $25 \mathrm{mg}$ sublingually and salbutamol 4 to $12 \mathrm{mg}$ orally, alone and in combination.

Isosorbide dinitrate reduced mean left ventricular filling pressure from 29 to $18 \mathrm{mmHg}$ and increased mean cardiac index from 1.7 to $2.01 / \mathrm{min}$ per $\mathrm{m}^{2}$, with no significant change in mean heart rate. Systemic arterial mean pressure fell from 85 to $72 \mathrm{mmHg}$.

Salbutamol increased cardiac index from 1.8 to $2.21 / \mathrm{min}$ per $\mathrm{m}^{2}$. There was no significant change in left ventricular filling pressure, heart rate, or systemic arterial pressure.

Compared with control, combined isosorbide dinitrate and salbutamol reduced left ventricular filling pressure from 27 to $19 \mathrm{mmHg}$ and increased cardiac index from 1.8 to $2.71 / \mathrm{min}$ per $\mathrm{m}^{2}$, with no significant change in heart rate. Systemic arterial pressure fell from 82 to $75 \mathrm{mmHg}$.

The reduction in left ventricular filling pressure by combined treatment was similar to that produced by isosorbide dinitrate alone, but the increase in cardiac index was significantly greater than that produced either by isosorbide dinitrate alone or salbutamol alone.

Combined sublingual isosorbide dinitrate and oral salbutamol have an additive effect in improving left ventricular performance in patients with severe chronic congestive cardiac failure.

Intravenous salbutamol has been shown to be effective in improving left ventricular function in patients needing circulatory support after openheart surgery ${ }^{1}$ and in patients with chronic congestive cardiac failure. ${ }^{2}$ Since salbutamol is predominantly a beta ${ }_{2}$-adrenergic agonist, its effect in improving cardiac function is presumably mediated principally through a reduction in left ventricular afterload.

Isosorbide dinitrate is also effective in improving left ventricular function in congestive cardiac failure, ${ }^{3-6}$ principally through preload reduction resulting from venodilatation. Combined salbutamol and isosorbide dinitrate treatment may, therefore, have an additive effect on the performance of the failing left ventricle.

This study was performed to determine the haemodynamic effects of oral salbutamol and sublingual isosorbide dinitrate, alone and in Received for publication 30 April 1979 combination, in patients with severe congestive cardiac failure, in an attempt to establish such a combination as a possible form of long-term oral treatment.

\section{Patients and methods}

Ten patients were studied, nine men and one woman, aged between 46 and 72 years. All were admitted to hospital because of severely incapacitating dyspnoea (grade III or IV, NYHA). In nine patients there was a long history of congestive cardiac failure secondary to ischaemic heart disease (seven patients) or probable alcoholic cardiomyopathy (two patients), while one patient had had an anterior myocardial infarction seven days previously (Table 1). One patient had had a permanent pacemaker implanted for chronic complete heart block; this patient was in a paced rhythm throughout the study. All patients had 
clinical and radiographic evidence of severe congestive heart failure. The clinical state of four was such that initial intensive treatment with intravenous inotropic agents and vasodilators was necessary. One patient was admitted in pulmonary oedema which improved with intravenous diuretic therapy. All patients had been treated with large doses of oral diuretics and one patient was taking digitalis.

On the day of the study the patients had received their normal dose of diuretics at least four hours before the study. Digitalis was withdrawn 24 hours before. At the time of the haemodyamic study the patients were judged to be clinically and haemodynamically stable, no inotropic or vasodilator agent having been administered within six hours of the start of the study. Informed consent was obtained in all cases.

A flow-directed thermodilution catheter was introduced into a subclavian vein percutaneously using a Desilets-Hoffman cannula and advanced to the pulmonary artery. In nine patients a first-pass radionuclide left ventriculogram was obtained. ${ }^{7}$ In nine patients systemic arterial pressure was obtained by cuff measurement (two patients) or by cannulating the radial artery with a 20 gauge Medicut (seven patients); in one patient the systemic arterial systolic pressure only could be obtained by cuff measurement. Pressures were measured using Bell \& Howell transducers and displayed on a Roche 144 portable monitor. The transducers were set for zero at mid-chest level. Cardiac output was measured by the thermodilution technique, ${ }^{8}$ each estimation being performed in triplicate.

After control measurements of heart rate, systemic arterial pressure, pulmonary arterial pressure, pulmonary artery wedge pressure (or pulmonary arterial end-diastolic pressure), and cardiac output, isosorbide dinitrate (Cedocard, Cedona, Holland) was administered sublingually in doses of between

Table 1 Patient data

\begin{tabular}{ccclcc}
\hline $\begin{array}{l}\text { Case } \\
\text { no. }\end{array}$ & $\begin{array}{c}\text { Age } \\
(y)\end{array}$ & Sex & $\begin{array}{l}\text { Aetiology of heart } \\
\text { failure }\end{array}$ & $\begin{array}{l}\text { Dose of } \\
\text { sublingual } \\
\text { ISDN }\end{array}$ & $\begin{array}{l}\text { Dose of } \\
\text { salbutamol }\end{array}$ \\
\hline 1 & 60 & F & IHD & $5 \mathrm{mg}$ & $4 \mathrm{mg}$ \\
2 & 64 & M & IHD & $10 \mathrm{mg}$ & $4 \mathrm{mg}$ \\
3 & 54 & M & Cardiomyopathy & $5 \mathrm{mg}$ & $4 \mathrm{mg}$ \\
4 & 71 & M & IHD (1 week after & $5 \mathrm{mg}$ & $4 \mathrm{mg}$ \\
& & & AMI) & $5 \mathrm{mg}$ & $4 \mathrm{mg}$ \\
5 & 63 & M & IHD & $15 \mathrm{mg}$ & $10 \mathrm{mg}$ \\
6 & 60 & M & IHD & $25 \mathrm{mg}$ & $6 \mathrm{mg}$ \\
7 & 59 & M & IHD & $5 \mathrm{mg}$ & $8 \mathrm{mg}$ \\
8 & 59 & M & IHD & $2.5 \mathrm{mg}$ & $8 \mathrm{mg}$ \\
9 & 72 & M & IHD & $15 \mathrm{mg}$ & $12 \mathrm{mg}$ \\
10 & 46 & $M$ & Cardiomyopathy & $15 \mathrm{mg}$ & \\
\hline
\end{tabular}

AMI, anterior myocardial infarct; IHD, ischaemic heart disease; ISDN, isosorbide dinitrate
2.5 and $25 \mathrm{mg}$ according to the individual response in left ventricular filling pressure (Table 1 ). Measurements were repeated after 15 minutes. A twohour period was allowed for haemodynamic recovery ${ }^{3}$ after which a second set of control measurements were made. Salbutamol $4 \mathrm{mg}$ was then administered orally. If an increase in cardiac output was not observed at 30 minutes (each of the five patients who responded to $4 \mathrm{mg}$ salbutamol did so at 30 minutes after administration), further doses were given until a response was seen (Table 1). To ensure a plateau had been reached in the response in cardiac output, cardiac output measurements were repeated after 30 minutes. The other haemodynamic measurements were then made, and all observations were repeated 15 minutes after isosorbide dinitrate given in the same dose as before.

\section{CALCULATIONS}

Mean pulmonary arterial and pulmonary artery wedge pressures were obtained by electronic integration. When systemic arterial pressure was measured by arterial cannulation the mean values were obtained by electronic integration. When blood pressure was obtained by cuff measurement the mean was calculated using the formula:

$$
\overline{\mathrm{AP}}=\mathrm{D}+(\mathrm{S}-\mathrm{D}) / 3^{9}
$$

where $\mathbf{A P}=$ arterial mean pressure $(\mathrm{mmHg})$; $\mathrm{D}=$ diastolic pressure $(\mathrm{mmHg})$; and $\mathrm{S}=$ systolic pressure ( $\mathrm{mmHg}$ ).

Left ventricular stroke work index (LVSWI) was calculated using the formula:

$$
\begin{array}{r}
\text { LVSWI }\left(\mathrm{g} \mathrm{m} \text { per m}^{2}\right)=\frac{\overline{(\mathrm{AP}}-\overline{\mathrm{PCWP}}) \times}{\text { SVI } \times 0.0136}
\end{array}
$$

where $\overline{\mathrm{PCWP}}=$ pulmonary artery wedge mean pressure $(\mathrm{mmHg})$, and $\mathrm{SVI}=$ stroke volume index $\left(\mathrm{ml} / \mathrm{m}^{2}\right)$.

Systemic vascular resistance (SVR) was calculated using the formula:

$$
\text { SVR }\left(\text { dynes } \mathrm{s} \mathrm{cm}^{-5}\right)=(\overline{\mathrm{AP}} / \mathrm{CO}) \times 80
$$

where $\mathrm{CO}=$ cardiac output $(1 / \mathrm{min})$.

Statistical analysis was by the paired Student's $t$ test.

\section{Results}

RADIONUCLIDE LEFT VENTRICULOGRAPHY There was severe reduction in left ventricular ejection fraction associated with diffuse hypokinesis 
in all nine patients in whom radionuclide left ventriculography was performed.

HAEMODYNAMIC DATA (Table 2)

Effects of isosorbide dinitrate

There was no significant change in mean heart rate.

The mean value for systemic arterial mean pressure fell from 85 to $72 \mathrm{mmHg}(15 \%, \mathrm{p}<0.01)$. The mean value for pulmonary arterial mean pressure fell from 37 to $24 \mathrm{mmHg}$ ( $35 \%, \mathrm{p}<0.001)$, while that for pulmonary artery wedge mean pressure fell from 29 to $18 \mathrm{mmHg}(38 \%, \mathrm{p}<0.001)$. Mean cardiac index increased from 1.7 to $2.01 / \mathrm{min}$ per $\mathrm{m}^{2}$ $(18 \%, \mathrm{p}<0.01)$ and stroke volume index increased from 18 to $22 \mathrm{ml} / \mathrm{m}^{2}(22 \%, p<0.01)$. There was no significant change in mean left ventricular stroke work index. Mean systemic vascular resistance fell from 2593 to 1777 dynes $\mathrm{sm}^{-5}(31 \%, \mathrm{p}<0.001)$.

\section{Effects of salbutamol}

There were no significant changes in medn values for heart rate or systemic arterial mean pressure. The mean value for pulmonary arterial mean pressure increased slightly from 35 to $37 \mathrm{mmHg}$ $(6 \%, p<0.05)$ but there was no significant change in the mean value for pulmonary artery wedge mean pressure. Mean cardiac index increased from 1.8 to $2.21 / \mathrm{min}$ per $\mathrm{m}^{2}(22 \%, \mathrm{p}<0.001)$. An increase was observed in all patients, except one in whom no change could be effected despite the administration of $12 \mathrm{mg}$ salbutamol (in this patient a large increase in cardiac index was observed when isosorbide dinitrate was administered concurrently) (Fig. 1). After salbutamol mean stroke volume index increased from 20 to $23 \mathrm{ml} / \mathrm{m}^{2}(15 \%, \mathrm{p}<0.005)$. Mean systemic vascular resistance fell from 2128 to 1748 dynes $\mathrm{s} \mathrm{cm}^{-5}(18 \%, \mathrm{p}<0.005)$ while mean stroke work index increased from 15 to $18 \mathrm{~g} \mathrm{~m}$ per $\mathrm{m}^{2}$ $(20 \%, \mathrm{p}<0.025)$.

\section{Effects of combined salbutamol and isosorbide} dinitrate

Compared with the second control period, combined

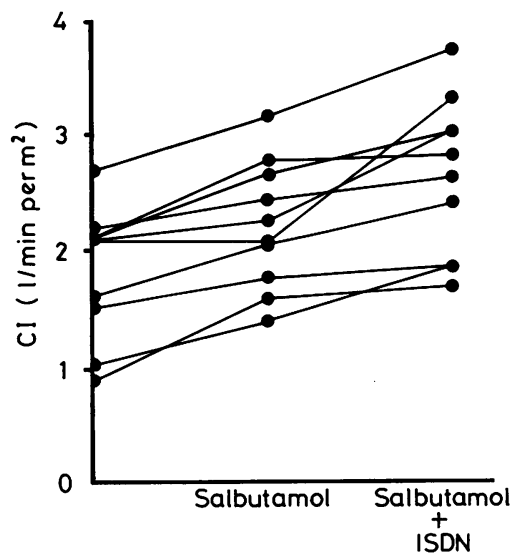

Fig. 1 Effects of oral salbutamol on cardiac index (CI) in individual patients. ISDN, isosorbide dinitrate.

salbutamol and isosorbide dinitrate produced no significant change in mean heart rate. Systemic arterial mean pressure fell from 82 to $75 \mathrm{mmHg}$ $(8 \%, \mathrm{p}<0.01)$. Pulmonary arterial mean pressure fell from mean 35 to $28 \mathrm{mmHg}(20 \%, p<0.001)$, while pulmonary artery wedge mean pressure fell from mean 27 to $19 \mathrm{mmHg}(30 \%, p<0.001)$. Cardiac index increased from 1.8 to $2.71 / \mathrm{min}$ per $\mathrm{m}^{2}$ $(50 \%, \mathrm{p}<0.001)$ and stroke volume index increased from 20 to $28 \mathrm{ml} / \mathrm{m}^{2}(40 \%, \mathrm{p}<0.001)$. Left ventricular stroke work index increased from 15 to $22 \mathrm{~g} \mathrm{~m}$ per $\mathrm{m}^{2}(47 \%, \mathrm{p}<0.001)$. Systemic vascular resistance fell from 2128 to 1326 dynes $\mathrm{s} \mathrm{cm}^{-5}$ (38\%, $\mathrm{p}<0.001$ ).

\section{Effects of salbutamol plus isosorbide dinitrate vs isosorbide dinitrate alone}

There was no significant change in mean heart rate with either isosorbide dinitrate alone or with the combination of salbutamol and isosorbide dinitrate, and there was no significant difference between the changes in systemic arterial mean pressure. The falls in mean values for pulmonary

Table 2 Haemodynamic effects of isosorbide dinitrate and salbutamol alone and in combination

\begin{tabular}{|c|c|c|c|c|c|c|}
\hline & $\begin{array}{l}\text { No. of } \\
\text { patients }\end{array}$ & Control 1 & $I S D N$ & Control 2 & Salbutamol & $\begin{array}{l}\text { Salbutamol } \\
\text { plus ISDN }\end{array}$ \\
\hline $\begin{array}{l}\text { Heart rate (beats/min) } \\
\text { Mean systemic arterial pressure (mmHg) } \\
\text { Mean pulmonary arterial pressure }\left(\mathrm{mmHg}^{2}\right) \\
\text { Left ventricular filling pressure }(\mathrm{mmHg}) \\
\text { Cardiac index }\left(1 / \mathrm{min} \text { per } \mathrm{m}^{2}\right) \\
\text { Stroke volume index }\left(\mathrm{ml} / \mathrm{m}^{2}\right) \\
\left.\text { Systemic vascular resistance (dynes } \mathrm{s} \mathrm{cm}{ }^{-5}\right) \\
\text { Left ventricular stroke work index }\left(\mathrm{g} \mathrm{m} / \mathrm{m}^{2}\right)\end{array}$ & $\begin{array}{r}95 \\
9 \\
10 \\
10 \\
10 \\
10 \\
9 \\
9\end{array}$ & $\begin{aligned} 96 & \pm 5 \cdot 4 \\
85 & \pm 4 \cdot 0 \\
37 & \pm 2 \cdot 2 \\
29 & \pm 1 \cdot 8 \\
1 \cdot 7 & \pm 0 \cdot 2 \\
18 & \pm 2 \cdot 2 \\
2593 & \pm 328 \\
15 & \pm 2 \cdot 8\end{aligned}$ & $\begin{aligned} 94 & \pm 5 \cdot 6 \\
72 & \pm 2 \cdot 1 \dagger \\
24 & \pm 2 \cdot 4 \ddagger \\
18 & \pm 1 \cdot 9 \ddagger \\
2 \cdot 0 & \pm 0 \cdot 2 \dagger \\
22 & \pm 2 \cdot 5 \\
1777 & \pm 249 \ddagger \\
18 & \pm 1 \cdot 9\end{aligned}$ & $\begin{aligned} 98 & \pm 4 \cdot 6 \\
82 & \pm 4 \cdot 7 \\
35 & \pm 2 \cdot 1 \\
27 & \pm 1 \cdot 6 \\
1 \cdot 8 & \pm 0 \cdot 2 \\
20 & \pm 2 \cdot 2 \\
2128 & \pm 249 \\
15 & \pm 2 \cdot 1\end{aligned}$ & $\begin{aligned} 101 & \pm 4 \cdot 0 \\
82 & \pm 4 \cdot 5 \\
37 & \pm 2 \cdot 0^{\star} \\
27 & \pm 1 \cdot 4 \\
2 \cdot 2 & \pm 0 \cdot 2 \ddagger \\
23 & \pm 2 \cdot 3 \dagger \\
1748 & \pm 176 t \\
18 & \pm 2 \cdot 9 \star\end{aligned}$ & $\begin{array}{r}100 \pm 3 \cdot 1 \\
75 \pm 4 \cdot 9 \ddagger \\
28 \pm 1 \cdot 9 \ddagger \\
19 \pm 1 \cdot 1 \ddagger \\
2 \cdot 7 \pm 0 \cdot 2 \ddagger \\
28 \pm 2 \cdot 5 \ddagger \\
1326 \pm 157 \ddagger \\
22 \pm 1 \cdot 1 \ddagger\end{array}$ \\
\hline
\end{tabular}

All results are expressed as mean \pm SEM.

ISDN, isosorbide dinitrate. ${ }^{\star} \mathrm{p}<0.05 ; \mathrm{tp}<0.01$; $\neq \mathrm{p}<0.001$. §Data for patient with fixed heart rate (permanent pacemaker) omitted. 
arterial mean pressure and pulmonary artery wedge mean pressure produced by the combination were similar to those produced by isosorbide dinitrate alone. Cardiac index increased to $2.01 / \mathrm{min}$ per $\mathrm{m}^{2}$ with isosorbide dinitrate alone, but to $2.71 / \mathrm{min}$ per $\mathrm{m}^{2}$ with the combination $(35 \%, \mathrm{p}<0.001)$; the corresponding values for stroke volume index were 22 and $28 \mathrm{ml} / \mathrm{m}^{2}(27 \%, \mathrm{p}<0.001)$ and for left ventricular stroke work index 18 and $22 \mathrm{~g} \mathrm{~m}$ per $\mathrm{m}^{2}$ $(22 \%, p<0.05)$. The fall in systemic vascular resistance with the combination was similar to that occurring after isosorbide dinitrate alone.

Effects of salbutamol plus isosorbide dinitrate vs salbutamol alone

There was no significant change in mean heart rate with either salbutamol alone or the combination. Systemic arterial mean pressure remained at $82 \mathrm{mmHg}$ with salbutamol alone, but fell to
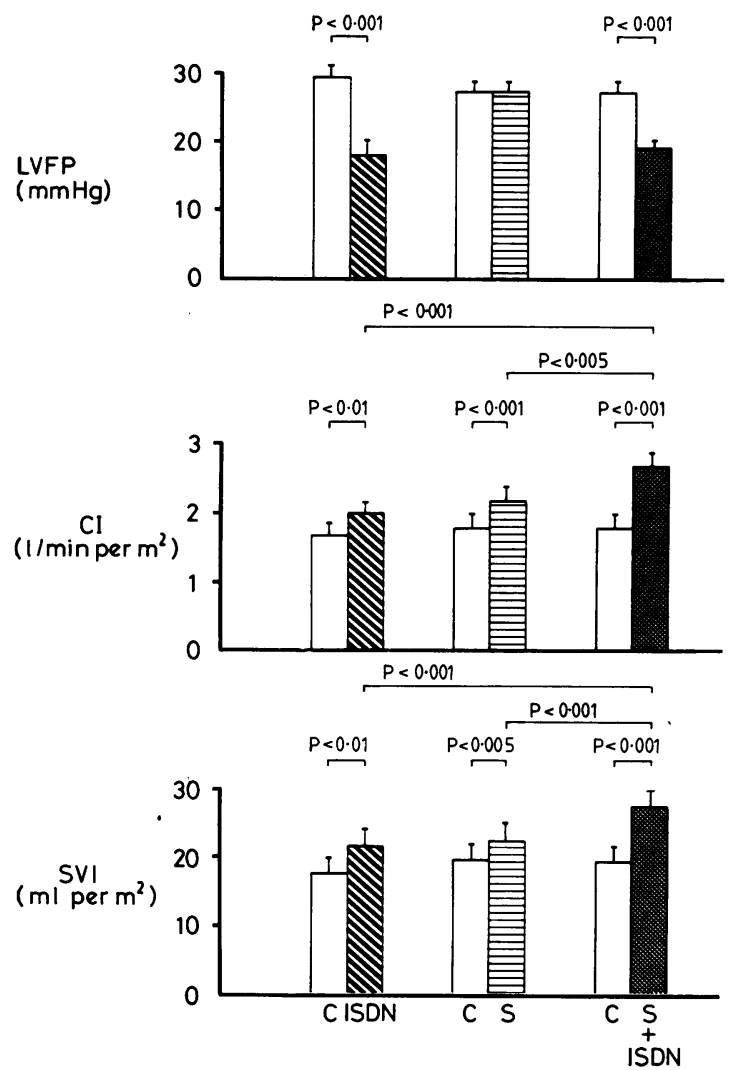

Fig. 2 Effects of isosorbide dinitrate (ISDN) and salbutamol $(S)$, alone and in combination, on mean values for cardiac index $(C I)$, stroke volume index (SVI), and left ventricular filling pressure (LVFP). Bars indicate \pm standard error of mean. $C=$ control.
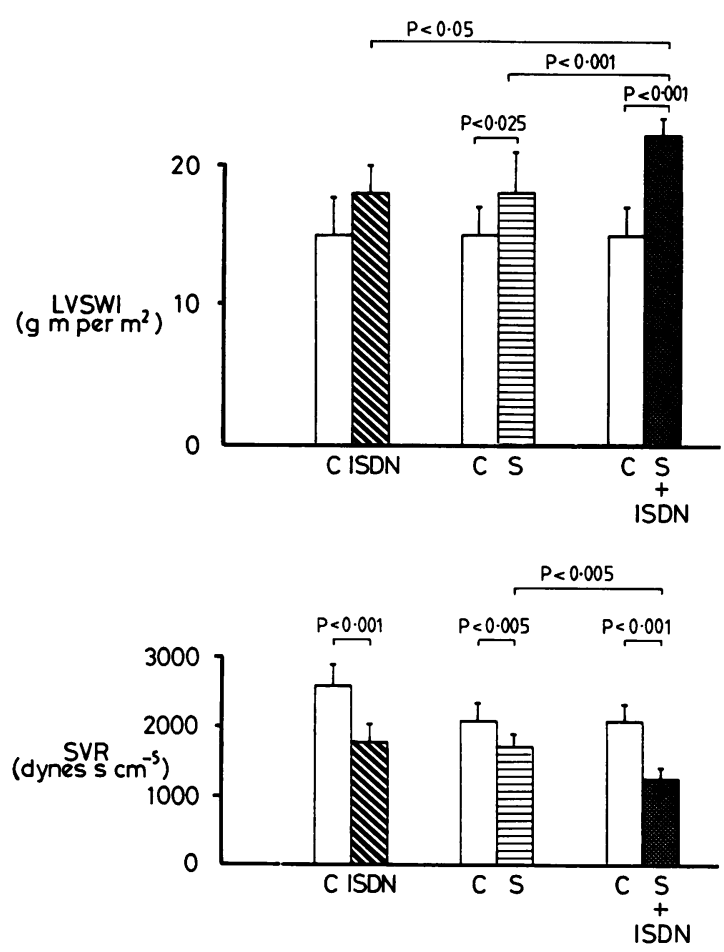

Fig. 3 Effects of isosorbide dinitrate (ISDN) and salbutamol $(S)$, alone and in combination, on mean values for left ventricular stroke work index (LVSWI), and systemic vascular resistance $(S V R)$. Bars indicate \pm standard error of mean.

$75 \mathrm{mmHg}$ with the combination $(8 \%, \mathrm{p}<0.02)$. Pulmonary arterial mean pressure increased slightly to $37 \mathrm{mmHg}$ with salbutamol alone but fell to $28 \mathrm{mmHg}$ with the combination $(24 \%, \mathrm{p}<0.001)$; the corresponding values for pulmonary artery wedge mean pressure were 27 and $19 \mathrm{mmHg}$ (30\%, $\mathrm{p}<0.001$ ). Cardiac index increased to $2.21 / \mathrm{min}$ per $\mathrm{m}^{2}$ with salbutamol alone and to $2 \cdot 7 \mathrm{l} / \mathrm{min}$ per $\mathrm{m}^{2}$ with the combination $(23 \%, \mathrm{p}<0.005)$; the corresponding values for stroke volume index were 23 and $28 \mathrm{ml} / \mathrm{m}^{2}(22 \%, \mathrm{p}<0.001)$ and for left ventricular stroke work index 18 and $22 \mathrm{~g} \mathrm{~m}$ per $\mathrm{m}^{2}(22 \%, \mathrm{p}<0.001)$. Systemic vascular resistance fell to 1748 dynes $\mathrm{s} \mathrm{cm}^{-5}$ with salbutamol alone and to 1326 dynes $\mathrm{s} \mathrm{cm}^{-5}$ with the combination $(24 \%, \mathrm{p}<0.005)$.

There were no unwanted effects of either drug, alone or in combination.

Changes in cardiac index, stroke volume index, left ventricular filling pressure, left ventricular stroke work index, and systemic vascular resistance are illustrated in Fig. 2 and 3. 


\section{Discussion}

In the severely ill patient with advanced congestive cardiac failure, an increase in left ventricular filling pressure and depression of cardiac output represent the clinically important manifestations of impaired cardiac function. The former, by causing pulmonary venous hypertension, produces dyspnoea and may result in pulmonary oedema and arterial hypoxaemia, while the latter leads to reduced renal perfusion, with the consequent exacerbation of sodium and fluid retention. The primary therapeutic objectives in the management of such patients are thus reduction in left ventricular filling pressure and augmentation of cardiac output. In recent years these objectives have been achieved pharmacologically using intravenous vasodilators including sodium nitroprusside, ${ }^{10} 11$ inotropic agents such as dopamine ${ }^{12}$ and dobutamine,$^{13}$ or a combination of vasodilator and inotropic agents. ${ }^{6} 14$

The search continues, however, for a suitable non-parenteral preparation for the long-term management of patients with chronic congestive cardiac failure. From experience gained with parenteral agents it appears that an ideal oral agent or combination of agents would dilate arterioles and veins, effecting reductions in left ventricular afterload and preload, respectively, together with an inotropic action. The summation of these effects should act to augment cardiac output and reduce left ventricular filling pressure, ideally without producing side effects such as tachycardia, hypotension, or arrhythmias.

Salbutamol is primarily a beta ${ }_{2}$-adrenergic agonist ${ }^{15}{ }^{16}$ but has a cardiac stimulant effect (beta ${ }_{1}$ ) albeit considerably less potent than isoprenaline. ${ }^{17}$ Its beneficial effect in congestive heart failure may therefore be principally the result of a reduction in left ventricular afterload by arteriolar vasodilatation, as suggested by Wyse et al., ${ }^{1}$ or to an inotropic effect as suggested by Sharma and Goodwin, ${ }^{2}$ or a combination of both. Isosorbide dinitrate has been shown to be effective in reducing left ventricular filling pressure in patients with congestive cardiac failure, with little or no change in resting cardiac output. $^{3} 4$ These observations have been interpreted as showing a potent venodilating effect with a less important arteriolar vasodilating effect. The combined properties of salbutamol and isosorbide dinitrate, both available for oral use, therefore fulfil in principle the criteria outlined for the long-term management of patients with chronic congestive cardiac failure.

In this study the principal effect of salbutamol was to improve cardiac output and stroke volume. The failure of the drug to reduce left ventricular filling

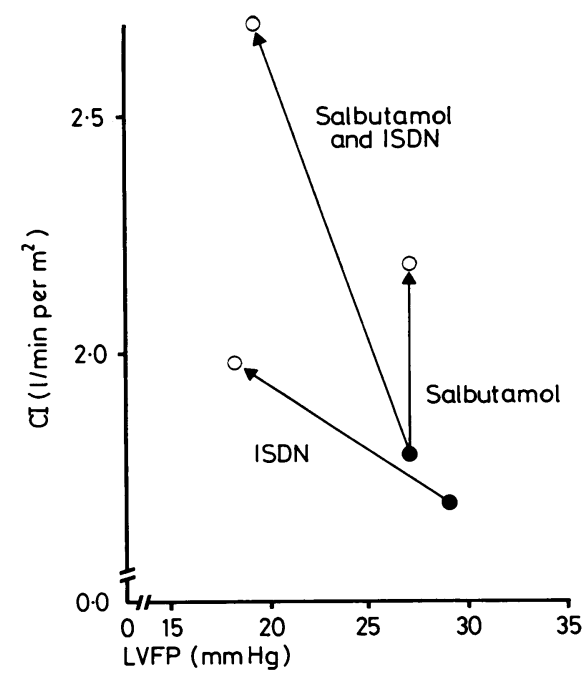

Fig. 4 Effects of isosorbide dinitrate (ISDN) and salbutamol, alone and in combination, on the relation between left ventricular filling pressure (LVFP) and cardiac index (CI).

pressure may have been the result of a venoconstricting effect since adrenergic stimulation has been shown to produce venoconstriction in dogs, ${ }^{18}$ though a recent study in $\operatorname{man}^{16}$ showed no effect of salbutamol on forearm venous tone.

In distinct contrast the principal effect of isosorbide dinitrate was to reduce left ventricular filling pressure. The observed haemodynamic effects of combined salbutamol and isosorbide dinitrate fulfilled the expectation of an additive effect in that there was a more comprehensive improvement in left ventricular performance than that produced by either agent alone (Fig. 4). This improvement was achieved without serious hypotension, tachycardia, or arrhythmias.

Oral salbutamol and sublingual isosorbide dinitrate appear to have a beneficial, additive effect in patients with severe, chronic congestive cardiac failure. Though the haemodynamic results of this study relate to the acute effects of such a combination they appear to establish this as a possible new therapeutic approach in the long-term management of such patients.

\section{References}

${ }^{1}$ Wyse SD, Gibson DG, Branthwaite MA. Haemodynamic effects of salbutamol in patients needing circulatory support after open-heart surgery. $\mathrm{Br} M e d \mathcal{F} 1974 ; 3$ : 502-3.

${ }^{2}$ Sharma B, Goodwin JF. Beneficial effect of salbutamol on cardiac function in severe congestive cardiomyopathy. Effect on systolic and diastolic function of the 
left ventricle. Circulation 1978; 58: 449-60.

${ }^{3}$ Gray R, Chatteriee K, Vyden JK, Ganz W, Forrester JS, Swan HJC. Hemodynamic and metabolic effects of isosorbide dinitrate in chronic congestive heart failure. Am Heart $\mathcal{F}$ 1975; 90: 346-52.

${ }^{4}$ Williams DO, Bommer WJ, Miller RR, Amsterdam EA, Mason DT. Hemodynamic assessment of oral peripheral vasodilator therapy in chronic congestive cardiac failure: prolonged effectiveness of isosorbide dinitrate. Am f Cardiol 1977; 39: 84-90.

${ }^{5}$ Stephens J, Camm J, Spurrell R. Improvement in exercise haemodynamics by isosorbide dinitrate in patients with severe congestive cardiac failure secondary to ischaemic heart disease. Br Heart $\mathcal{F} 1978 ; 40$ : 832-7. ${ }^{6}$ Stephens J, Dymond D, Spurrell R Enhancement by isosorbide dinitrate of haemodynamic effects of dopamine in chronic congestive cardiac failure. $\mathrm{Br}$ Heart $\mathcal{F} 1978$; 40: 838-44.

'Dymond DS, Jarritt PH, Britton KE, Spurrell RAJ. Detection of post infarction left ventricular aneurysm by first-pass radionuclide ventriculography using a multi-crystal gamma camera. $B r$ Heart $\mathcal{F} 1979 ; 41$ : 68-78.

${ }^{8} \mathrm{Ganz}$ W, Swan HJC. Measurement of blood flow by thermodilution. Am f Cardiol 1972; 29: 241-6.

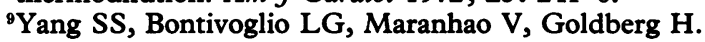
From cardiac catheterisation data to haemodynamic parameters. Philadelphia: F. A. Davies, 1972: 9.

${ }^{10}$ Franciosa JA, Guiha NH, Limas CJ, Rodiguera E, Cohn JN. Improved left ventricular function during nitroprusside infusion in acute myocardial infarction. Lancet 1972; 1: 650-4.

${ }^{11}$ Chatterjee K, Parmley WP, Ganz W et al. Hemodyna- mic and metabolic responses to vasodilator therapy in acute myocardial infarction. Circulation 1973; 48: 1183-93.

${ }^{12}$ Beregovich J, Bianchi C, Rubler S, Lomnitz E, Cagin N, Levitt B. Dose related haemodynamic and renal effects of dopamine in congestive cardiac failure. Am Heart $\mathcal{F}$ 1974; 87: 550-7.

${ }^{13}$ Leier CV, Webel J, Bush CA. The cardiovascular effects of the continuous infusion of dobutamine in patients with severe cardiac failure. Circulation 1977; 56: 468-72.

${ }^{14}$ Miller RR, Awan NA, Joyce JA et al. Combined dopamine and nitroprusside therapy in congestive heart failure. Greater augmentation of cardiac performance by addition of inotropic stimulation to afterload reduction. Circulation 1977; 55: 881-4.

${ }^{15}$ Cullum VA, Farmer JB, Jack D, Levy GP. Salbutamol: a new, selective $\beta$-adrenoceptive receptor stimulant. $B r$ F Pharmacol 1969; 35: 141-51.

${ }^{16}$ Zsotér TT, Epstein SW. Effect of salbutamol on the perpipheral circulation in man. Chest $1973 ; 64: 465-71$.

${ }^{17}$ Daly MJ, Farmer JB, Levy GP. Comparison of the bronchodilator and cardiovascular actions of salbutamol, isoprenaline and orciprenaline in guinea-pigs and dogs. Br f Pharmacol 1971 ; 42: 624-38.

${ }^{18}$ Kaiser GA, Ross J Jr, Braunwald E. Alpha and beta adrenergic receptor mechanisms in the systemic venous bed. F Pharmacol Exp Ther 1964; 144: 156-62.

Requests for reprints to Dr J D Stephens, Department of Cardiology, St. Bartholomew's Hospital, London EC1A 7BE. 